\title{
Effects of Natural Mucilage as an Edible Coating on Quality Improvement of Freshly-cut apples
}

\author{
Mohammad Noshad ${ }^{* 1}$, Mostafa Rahmati-Joneidabad², Zahra Badvi² \\ 1- Department of Food Science and Technology, Faculty of Animal Science and Food Technology, Agricultural Sciences and Natural Resources \\ University of Khuzestan, Mollasani, Iran \\ 2- Department of Horticultural Science, Faculty of Agriculture, Agricultural Sciences and Natural Resources University of Khuzestan, Mollasani, Iran
}

\section{A B S T R A C T}

Background and Objectives: Production and consumption of freshly-cut fruits have been increased in recent decades. One of the major problems in storage of freshly-cut fruits, the color change, is a result of the oxidative reactions of phenolic compounds by polyphenol oxidases. Various treatments such as coating and refrigeration are used to improve quality and shelf-life of the fresh-cut fruits. The aim of this study was to assess effects of various functional mucilages as polysaccharide food coatings on qualitative parameters of freshly-cut apple slices during cold storage.

Materials and Methods: In this study, active edible coatings, using Plantago major, P. psyllium and Descurainia Sophia mucilages, were prepared. Then, effects of various coating solutions on physicochemical characterizes of freshlycut apple slices were assessed during cold storage.

Results: Results indicated that samples treated with $D$. sophia included the greatest titrable acidity value and the lowest brix and browning index (BI), compared to another treatment. On Day 10 of storage, samples treated with P. psyllium showed the highest contents of vitamin $\mathrm{C}$, firmness and inhibitory effects on the bacterial growth. Use of P. psyllium, as an edible coating, produced a $0.7 \log \mathrm{CFU} / \mathrm{g}$ decrease in bacterial counts.

Conclusions: In conclusion, P. psyllium L. mucilage is recommended as a novel edible coating to improve quality of freshly-cut apples.

Keywords: Natural mucilage, Functional properties, Freshly-cut apple, Shelf-life

\section{Introduction}

Production and consumption of freshly-cut fruits have been increased in recent decades. One of the problems in the storage of freshly-cut fruits is the color change resulted from the oxidative reactions of phenolic compounds with polyphenol oxidases. Various treatments such as coating and refrigeration are used to improve quality and extend shelf-life of the fresh-cut fruits. Inhibitory effects of edible coating in decrease of respiration and enzymatic browning are associated to its capability of extending a semipermeable barrier against gases and water steam that increase the preservation time of freshly-cut fruits (1, 2 ). Nowadays, use of mucilages is getting popular due to its availability, safety, low process price and functional properties. Mucilages are non-sticky heteropolysaccharides which are often found in medicinal plants. Mucilages generally contain two or more various monosaccharide units such as Larabinose, L-xylose, D-galactose and D-galacturonic acid (3-7). Ribwot with the scientific name of $P$. major L. is a medicinal plant that includes functional and medicine properties such as antioxidant, antimicrobial, anti-infective, anti- cancer and antiinflammatory properties. This plant has been used in treatments for many centuries worldwide $(8,9)$. Descurainia Sophia. L, also known as fixweed, is a plant seed in Brassicaceae family and a yearly (seldom biennial) pioneer herb which is adopted to dry environments. It is one of the most medicinal plants used in Iranian traditional medicine. A few studies have demonstrated antioxidant, antiinflammatory and antipyretic effects of D. Sophia. 
L(10). Another medicinal plants, P. psyllium L, is a yearly herb which needs dry sunny weather for the maturation of its seeds. The seeds contain mucilage and have been used for centuries for treatment purposes. A few studies have shown pharmaceutical characteristics (as a blood pressure reducer) of $P$. psyllium L (11). Since no studies have been carried out on natural mucilages as edible coatings, this study was carried out to assess effects of various functional mucilages as polysaccharide food coatings on qualitative parameters of freshly-cut apple slices during cold storage.

\section{Materials and Methods}

Apples (Malus domestica Borkh) of approximately similar sizes were purchased from a local store in Ahwaz, Iran, and kept at $4{ }^{\circ} \mathrm{C}$. The $P$. major L, D. Sophia. L and $P$. psyllium $\mathrm{L}$ seeds were purchased from a grocery herb shop in Ahvaz, Iran. Other chemicals used in this study were provided by Merck, Damstadt, Germany.

Fruit preparation: Fruits were dried for $20 \mathrm{~min}$ after washed with $2 \%(\mathrm{v} / \mathrm{v})$ sodium hypochlorite for $3 \mathrm{~min}$. Unstained steel knives were used to remove cores and cut the fruits into eight similar pieces.

Mucilage extraction: For the extraction of mucilages in similar conditions, a seed with a 1:20 (w/v) ratio to distilled water was heated at $75^{\circ} \mathrm{C}$ for $1 \mathrm{~h}$ at $160 \mathrm{rpm}$ using adjustable temperature-controlled heater after preliminary tests. Then, extracted mucilage was filtered and stored in a cool condition until use. Apple slices were dipped into the extracted mucilage at 25 ${ }^{\circ} \mathrm{C}$. These were stored at room temperature for $20 \mathrm{~min}$ to dry. Then, the apple slices were stored at $4{ }^{\circ} \mathrm{C}$ for 10 days in PET packages covered with cellophane.

Browning index (BI): An image processing system (Canon Power Shot SX60 HS, Japan) was used to capture images. MATLAB R2014a (MathWorks, Natick, Ma, USA) was used to compare the images and extracted CIELAB color parameters. The BI was calculated using the following formula (12):

$\mathrm{BI}=\frac{[100(\mathrm{x}-0.31)]}{0.172}$

Where, $x=\left(a^{*}+1.75 L^{*}\right) /\left(5.645 L^{*}+a^{*}-3.012 b *\right)$.

Texture: A hand-held penetrometer was used to assess the firmness. Average values of the firmness were represented in Newtons (N) (13).
Microbiological analysis: A method by Chen et al. (2016) was used to analyze total bacteria. Briefly, 10 gr of the samples were mixed with $50 \mathrm{ml}$ of $0.1 \%$ peptone and homogenized. Agar plates were used to count the total bacteria. Plates were stored at $37{ }^{\circ} \mathrm{C}$ for $48 \mathrm{~h}$ (12).

Vitamin C: To assess the content of vitamin C, $2 \mathrm{ml}$ of the apple juice were mixed with $8 \mathrm{ml}$ of deionized water, $10 \mathrm{ml}$ of Potassium iodide (KI) and three drops of $1 \%$ starch. A $0.01 \mathrm{M} \mathrm{Cu}_{2} \mathrm{SO}_{4}$ solution was used for the titration. The content of vitamin $\mathrm{C}$ was calculated as follows $(14,15)$ :

Vitamin $\mathrm{C}(\%)=[(\mathrm{V} \times 0.88) / \mathrm{Y}] \times 100$

Where, $\mathrm{V}$ was the volume of copper sulfate and $\mathrm{Y}$ the total volume of the sample.

Titratable acidity: Briefly, $2 \mathrm{ml}$ of the apple juice were mixed with $20 \mathrm{ml}$ of the deionized water. Phenol phthalein was used as indicator. The $0.1 \mathrm{~N} \mathrm{NaOH}$ was added to the solution until a pink color appeared. The total acidity was expressed as the percentage of malic acid as follows $(16,17)$ :

Total acidity $(\%)=[($ Meq wt $\times \mathrm{N} \times \mathrm{V}) / \mathrm{Y}] \times 100$

Where, meq wt was the miliequivalent of malic acid, $\mathrm{N}$ the normality of $\mathrm{NaOH}, \mathrm{V}$ the volume of $\mathrm{NaOH}$, and $\mathrm{Y}$ the volume of sample juice.

Total phenolic concentration: In general, $30 \mu \mathrm{L}$ of apple juice were mixed with $2.5 \mathrm{ml}$ of foline ciocalteu $(10 \% \mathrm{v} / \mathrm{v}), 2.37 \mathrm{~mL}$ of deionized water and $2 \mathrm{~mL}$ of sodium carbonate $(20 \% \mathrm{w} / \mathrm{v})$. A spectrophotometer (WPA UV 1101, Biotech Photometer, Cambridge, UK) was used to measure optical density (OD) of samples at $760 \mathrm{~nm}$. The phenol content was expressed as $\mathrm{mg} / \mathrm{mL}(12,18)$.

Polyphenol oxidase activity (PPO): Briefly, $10 \mathrm{gr}$ of the apple tissue were mixed with $50 \mathrm{~mL}$ of potassium phosphate buffer and then $10 \mathrm{~mL}$ of the extract were centrifuged at $6,000 \mathrm{rpm}$ for $10 \mathrm{~min}$. To assess the activity of polyphenol oxidase, $1 \mathrm{~mL}$ of sodium phosphate buffer, $1 \mathrm{~mL}$ of tirozine and $900 \mu \mathrm{L}$ of double deionized water were added into a cuvette and then $100 \mu \mathrm{L}$ of the enzyme extract were added into the cuvette. Then, OD of the solution was measured at Minutes $0,2,4,6,8$ and 10 at $280 \mathrm{~nm}$ using spectrophotometer. (19).

Total antioxidant activity: Briefly, $0.1 \mathrm{~mL}$ of the apple extract were mixed with $2.9 \mathrm{~mL}$ of $0.1 \mathrm{mM}$ DPPH in ethanol. A spectrophotometer (WPA UV 
1101, Biotech Photometer, Cambridge, UK) was used to measure the optical density (OD) of samples at 515 $\mathrm{nm}$. The following formula was used to calculate total antioxidant activity (20):

Inhibition (\%) $=\left[\frac{(\text { A515 blank }- \text { A515 sample })}{\mathrm{A} 515 \text { blank }}\right] \times 100$

Statistical analysis: The analysis of variance (ANOVA) and the Duncan's multiple range test were used to analyze data using SPSS software v.23.0 (IBM Analytics, USA).

\section{Results}

Titrable acidity: Results of the effects of various edible coatings on the mean titratable acidity of the samples are indicated in Table 1. In Day 1 of storage, the greatest titrable acidity value was observed in control samples $(0.160 \pm 0.01 \%)$, whereas the lowest was seen in samples treated with $P$. major $(0.082 \pm 0.01 \%)$. Increased storage time was linked to decreased acidity of all treatments. On Day 10 of storage, no significant differences were seen between the controls and samples treated with $P$. psyllium and $P$. major, while samples treated with $D$. sophia included the greatest titrable acidity value in comparison with other treatments.

Brix: Table 2 shows brix of the apple samples during cold storage. Results showed a significant difference between the control and other treatments. Increased storage time was linked to increased solid soluble materials in treatments.

Vitamin C: Contents of vitamin $\mathrm{C}$ in the samples are shown in Table 3. Results demonstrated that treatment with P. psyllium included the highest content of vitamin C during a 10-day storage. During the storage, the content of vitamin $\mathrm{C}$ in all treatments decreased gradually.

Table 1. Effects of edible coatings on titratable acidity (TA, mg malic acid $\mathrm{L}^{-1}$ of juice) of freshly-cut apples during cold storage at $4{ }^{\circ} \mathrm{C}$

\begin{tabular}{lcccc}
\hline & \multicolumn{4}{c}{ Storage time (days) } \\
\cline { 2 - 5 } Treatment & 1 & 3 & 6 & 10 \\
\hline Control & $0.160 \pm 0.01 \mathrm{aA}$ & $0.059 \pm 0.004 \mathrm{bB}$ & $0.054 \pm 0.007 \mathrm{bB}$ & $0.032 \pm 0.008 \mathrm{bC}$ \\
Plantago major & $0.082 \pm 0.01 \mathrm{dA}$ & $0.050 \pm 0.004 \mathrm{bB}$ & $0.045 \pm 0.01 \mathrm{bB}$ & $0.041 \pm 0.007 \mathrm{bB}$ \\
Plantago psyllium & $0.097 \pm 0.01 \mathrm{cA}$ & $0.059 \pm 0.004 \mathrm{bB}$ & $0.054 \pm 0.007 \mathrm{bBC}$ & $0.043 \pm 0.004 \mathrm{bC}$ \\
Descurainia sophia & $0.122 \pm 0.007 \mathrm{bA}$ & $0.113 \pm 0.008 \mathrm{aA}$ & $0.097 \pm 0.004 \mathrm{aB}$ & $0.092 \pm 0.01 \mathrm{aB}$ \\
\hline
\end{tabular}

Means with different letters in the same column and raw are significantly different using LSD test $(\mathrm{P}<0.05)$. Each value represents mean \pm standard deviation of three replicates.

Table 2. Effects of edible coatings on TSS ( ${ }^{\circ}$ Brix) of freshly-cut apples during cold storage at $4{ }^{\circ} \mathrm{C}$

\begin{tabular}{lcccc}
\hline & \multicolumn{4}{c}{ Storage time (days) } \\
\cline { 2 - 5 } Treatment & 1 & 3 & 6 & 10 \\
\hline Control & $10.53 \pm 0.15 \mathrm{aD}$ & $11.06 \pm 0.11 \mathrm{aC}$ & $11.83 \pm 0.058 \mathrm{aB}$ & $12.10 \pm 0.17 \mathrm{aA}$ \\
Plantago major & $9.06 \pm 0.05 \mathrm{dD}$ & $9.30 \pm 0.10 \mathrm{cC}$ & $10.10 \pm 0.17 \mathrm{cB}$ & $10.53 \pm 0.11 \mathrm{cA}$ \\
Plantago psyllium & $9.26 \pm 0.05 \mathrm{cC}$ & $10.23 \pm 0.05 \mathrm{bB}$ & $10.40 \pm 0.10 \mathrm{bA}$ & $10.53 \pm 0.058 \mathrm{cA}$ \\
Descurainia sophia & $10.233 \pm 0.11 \mathrm{bB}$ & $10.23 \pm 0.058 \mathrm{bB}$ & $10.36 \pm 0.15 \mathrm{bB}$ & $10.73 \pm 0.058 \mathrm{bA}$ \\
\hline
\end{tabular}

Means with different letters in the same column and raw are significantly different using LSD test $(\mathrm{P}<0.05)$. Each value represents mean \pm standard deviation of three replicates.

Table 3. Effects of edible coatings on ascorbic acid (mg AA/100 g FW) of freshly-cut apples during cold storage at $4{ }^{\circ} \mathrm{C}$

\begin{tabular}{lcccc}
\hline & \multicolumn{4}{c}{ Storage time (days) } \\
\cline { 2 - 5 } Treatment & 1 & 3 & 6 & 10 \\
\hline Control & $16.13 \pm 0.5 \mathrm{aA}$ & $11.44 \pm 0.88 \mathrm{bB}$ & $10.58 \pm 1.01 \mathrm{bBC}$ & $9.97 \pm 1.06 \mathrm{aC}$ \\
Plantago major & $12.32 \pm 0.88 \mathrm{cA}$ & $12.32 \pm 0.88 \mathrm{bA}$ & $11.14 \pm 0.50 \mathrm{bB}$ & $10.56 \pm 0.88 \mathrm{aB}$ \\
Plantago psyllium & $14.96 \pm 0.88 \mathrm{bAB}$ & $14.96 \pm 0.88 \mathrm{aA}$ & $13.20 \pm 0.88 \mathrm{aB}$ & $11.14 \pm 0.5 \mathrm{aC}$ \\
Descurainia sophia & $13.78 \pm 1.34 \mathrm{bcA}$ & $11.44 \pm 0.88 \mathrm{bB}$ & $10.853 \pm 1.01 \mathrm{bBC}$ & $9.97 \pm 1.01 \mathrm{aC}$ \\
\hline
\end{tabular}

Means with different letters in the same column and raw are significantly different using LSD test $(\mathrm{P}<0.05)$. Each value represents mean \pm standard deviation of three replicates. 
Polyphenol oxidase activity (PPO): Table 4 demonstrates the effects of various coatings on PPO of apple samples during the storage. The PPO of freshly-cut apples increased with significant differences between the control and other treatments.

Firmness: Results from the effects of various edible coatings on apple firmness are shown in Table 5. These results showed significant differences between the control and other samples treated during a 10-day storage. During the storage, firmness of the samples increased gradually.

Total phenol content: Table 6 includes results from effects of various coatings on total phenol content of the samples. On Day 1 of storage, no significant differences were seen between the control and other treatments while on Day 10, significant differences were reported between the samples treated with $P$. psyllium and D. Sophia in comparison with the control. Increased storage time was linked to significantly decreased total phenol contents of the samples treated with $P$. major and the control, while no significantly decreased total phenol contents were seen in the samples treated with P. psyllium and D. Sophia.

Browning index (BI): Table 7 shows BI of freshly-cut apples during the storage. On Day 1 of storage, no significant differences were observed comparing control and $P$. major treated samples with $P$. psyllium and $D$. Sophia treated samples. However, significant differences were seen between all treatments on Day 10 of storage. In general, BI decreased gradually in all treatments during the storage.

Table 4. Effects of edible coatings on PPO of freshly-cut apples during cold storage at $4{ }^{\circ} \mathrm{C}$

\begin{tabular}{lcccc}
\hline & \multicolumn{4}{c}{ Storage time (days) } \\
\cline { 2 - 5 } Treatment & 1 & 3 & 6 & 10 \\
\hline Control & $0.060 \pm 0.008 \mathrm{aB}$ & $0.24 \pm 0.004 \mathrm{aA}$ & $0.27 \pm 0.016 \mathrm{aA}$ & $0.28 \pm 0.006 \mathrm{aA}$ \\
Plantago major & $0.043 \pm 0.006 \mathrm{abC}$ & $0.11 \pm 0.007 \mathrm{bB}$ & $0.14 \pm 0.016 \mathrm{bA}$ & $0.16 \pm 0.015 \mathrm{bA}$ \\
Plantago psyllium & $0.026 \pm 0.005 \mathrm{bC}$ & $0.043 \pm 0.004 \mathrm{cBC}$ & $0.060 \pm 0.027 \mathrm{~dB}$ & $0.15 \pm 0.006 \mathrm{bA}$ \\
Descurainia sophia & $0.03 \pm 0.01 \mathrm{bD}$ & $0.10 \pm 0.011 \mathrm{bC}$ & $0.13 \pm 0.012 \mathrm{cB}$ & $0.15 \pm 0.016 \mathrm{bA}$ \\
\hline
\end{tabular}

Means with different letters in the same column and raw are significantly different using LSD test $(\mathrm{P}<0.05)$. Each value represents mean \pm standard deviation of three replicates.

Table 5. Effects of edible coatings on firmness (N) of freshly-cut apples during cold storage at $4{ }^{\circ} \mathrm{C}$

\begin{tabular}{lllll}
\hline & \multicolumn{4}{c}{ Storage time (days) } \\
\cline { 2 - 5 } Treatment & 1 & 3 & 6 & 10 \\
\hline Control & $2.33 \pm 0.058 \mathrm{aA}$ & $2.00 \pm 0.3 \mathrm{abB}$ & $1.70 \pm 0.10 \mathrm{bC}$ & $1.44 \pm 0.053 \mathrm{cD}$ \\
Plantago major & $2.16 \pm 0.11 \mathrm{abA}$ & $1.93 \pm 0.3 \mathrm{abAB}$ & $1.81 \pm 0.07 \mathrm{bB}$ & $1.75 \pm 0.051 \mathrm{bB}$ \\
Plantago psyllium & $2.23 \pm 0.15 \mathrm{abA}$ & $2.15 \pm 0.05 \mathrm{aA}$ & $2.10 \pm 0.2 \mathrm{aA}$ & $2.09 \pm 0.010 \mathrm{aA}$ \\
Descurainia sophia & $2.07 \pm 0.059 \mathrm{bA}$ & $1.76 \pm 0.20 \mathrm{bB}$ & $1.60 \pm 0.10 \mathrm{bBC}$ & $1.43 \pm 0.05 \mathrm{cC}$ \\
\hline
\end{tabular}

Means with different letters in the same column and raw are significantly different using LSD test $(\mathrm{P}<0.05)$. Each value represents mean \pm standard deviation of three replicates.

Table 6. Effects of edible coatings on total phenolic contents $(\mathrm{mg} / \mathrm{kg})$ of freshly-cut apples during cold storage at $4^{\circ} \mathrm{C}$

\begin{tabular}{lcccc}
\hline & \multicolumn{4}{c}{ Storage time (days) } \\
\cline { 2 - 5 } Treatment & 1 & 3 & 6 & 10 \\
\hline Control & $817.92 \mathrm{aA}$ & $425.08 \mathrm{bB}$ & $417.72 \mathrm{cB}$ & $362.86 \mathrm{bB}$ \\
Plantago major & $818.84 \mathrm{aA}$ & $690.96 \mathrm{aB}$ & $576.88 \mathrm{bB}$ & $450.84 \mathrm{bC}$ \\
Plantago psyllium & $718.56 \mathrm{aA}$ & $770.08 \mathrm{aA}$ & $735.12 \mathrm{aA}$ & $670.72 \mathrm{aA}$ \\
Descurainia sophia & $779.28 \pm \mathrm{aA}$ & $761.80 \mathrm{aA}$ & $712.35 \mathrm{aA}$ & $702.92 \mathrm{aA}$ \\
\hline
\end{tabular}

Means with different letters in the same column and raw are significantly different using LSD test $(\mathrm{P}<0.05)$. Each value represents mean \pm standard deviation of three replicates.

Table 7. Effects of edible coatings on browning index of freshly-cut apples during cold storage at $4{ }^{\circ} \mathrm{C}$

\begin{tabular}{lcccc} 
& \multicolumn{4}{c}{ Storage time (days) } \\
\cline { 2 - 5 } Treatment & 1 & 3 & 6 & 10 \\
\hline Control & $34.78 \pm 1.6 \mathrm{aD}$ & $50.76 \pm 1.11 \mathrm{bC}$ & $58.64 \pm 1.01 \mathrm{aB}$ & $65.44 \pm 1.49 \mathrm{aA}$ \\
Plantago major & $34.17 \pm 0.43 \mathrm{aD}$ & $41.13 \pm 0.9 \mathrm{dC}$ & $48.77 \pm 2.1 \mathrm{bB}$ & $62.82 \pm 1.26 \mathrm{bA}$ \\
Plantago psyllium & $30.20 \pm 1.54 \mathrm{bD}$ & $44.06 \pm 2.5 \mathrm{cC}$ & $47.54 \pm 1.12 \mathrm{bB}$ & $59.70 \pm 1.08 \mathrm{cA}$ \\
Descurainia sophia & $31.42 \pm 1.44 \mathrm{bD}$ & $49.12 \pm 1.53 \mathrm{aC}$ & $53.71 \pm 1.42 \mathrm{bB}$ & $57.35 \pm 1.46 \mathrm{dA}$
\end{tabular}

Means with different letters in the same column and raw are significantly different using LSD test $(\mathrm{P}<0.05)$. Each value represents mean \pm standard deviation of three replicates. 
Microbial count: Freshly-cut apples are good environments for the growth of microorganisms because of their high water and sugar contents. Effects of various coatings on the bacterial count of freshly-cut apples during a 10-day storage are shown in Fig 1. During the storage, bacterial count of all treatments increased gradually. However, samples treated with $P$. psyllium and the control respectively demonstrated the highest and lowest inhibitory effects on the bacterial growth during ten days of storage.

\section{Discussion}

\section{Titrable acidity}

On Day 10 of storage, samples treated with D. sophia included the greatest titrable acidity value compared to other treatments. This was possibly seen because coating with $D$. Sophia delayed ripening and senescence processes of fruits compared to other treatments; therefore, organic acids were protected because of absence of consumption and/or transformation of simple sugars in freshly-cut apples.

Brix: Results from the current study were similar to those from studies by Roble et al. (2011) and Jafari et al. (2018) $(21,22)$. The major reason for increased solid soluble materials in the samples was likely the maturity of fruits (23). Increase in brix of D. Sophia treated samples was lower than increasing in other samples; hence, D. Sophia could delay ripening and senescence processes in fruits in comparison to other treatments.
Vitamin C: Increase in vitamin C of the samples during the storage might be resulted from increased oxidation due to decreased water contents (24). However, other researchers showed that decreased vitamin $\mathrm{C}$ was seen because of the activities of phenol oxidase and ascorbic acid oxidase (25).

Polyphenol oxidase activity (PPO): Increase in PPO of control samples was higher than that of other treatment samples. Use of coating modified the atmosphere around the freshly-cut apples and increased $\mathrm{CO}_{2}$ concentration decreased respiration rates and oxidative reactions of phenols, leading to less activities of polyphenol oxidase (26).

Firmness: Decrease in pectin compounds is the major factor in softening of fruit tissues. Activities of polygalacturonase and pectin methyl esterase may result in pectin compound destruction, which is linked to destroy of middle lamella (27). Based on the results, samples treated with $P$. psyllium and the control sample respectively demonstrated the highest and lowest level of tissue firmness during ten days of storage. Therefore, use of $P$. psyllium as edible coating effectively preserved tissue firmness of the freshly-cut apples during a 10-day storage (26). In 2011, Qi et al. showed that coating with $1 \%$ of chitosan, $0.5 \%$ of calcium chloride and $2 \%$ of ascorbic acid efficiently preserved firmness of the freshly-cut apples during the storage (26).

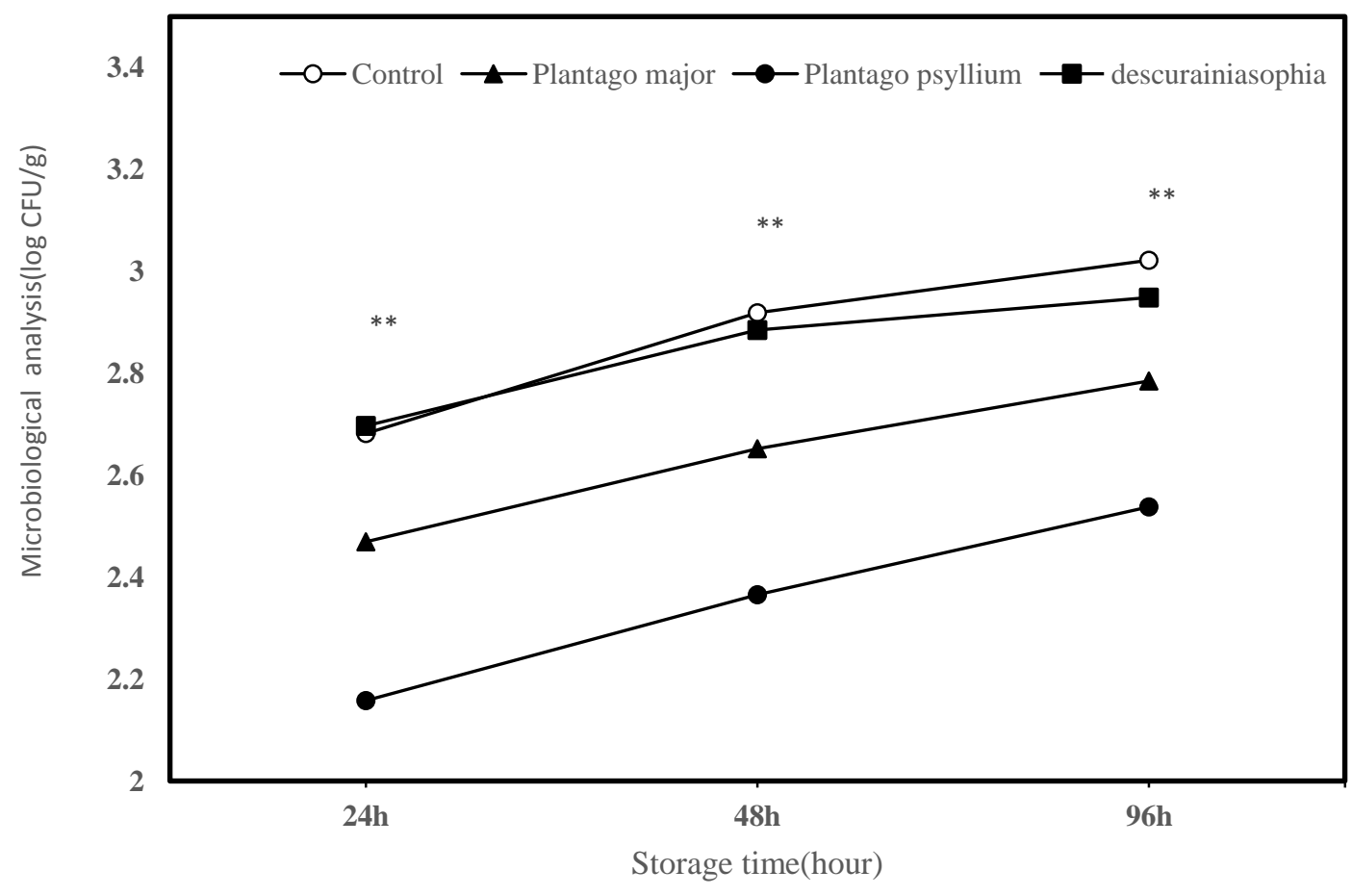

Figure 1. Effects of edible coatings on microbiological analysis (log CFU/g) of freshly-cut apples in the end of storage at $4{ }^{\circ}$ C. Controls included uncoated, P. major, P. psyllium and D. Sophia 
Total phenol: Decreased total phenol during the storage was possibly seen due to destruction of cellular structure as a result of the senescence process in apple cuts (28). Therefore, use of $P$. psyllium and D. Sophia as edible coatings effectively preserved total phenol contents of the freshly-cut apples during a 10-day storage.

Browning index (BI): Results showed that samples treated with $D$. Sophia and the control sample respectively included the lowest and highest levels of BI during ten days of storage. Because increased activity of PPO increased browning enzyme reactions, the freshly-cut apples turned browner. Therefore, use of $D$. Sophia as edible coating decreased activity of PPO and preserve of further phenolic compounds decreased browning of the freshly-cut apples. These hence effectively preserved color of the freshly-cut apples during a 10-day storage (29). In 2011, Chauhan et al. demonstrated that shellac and aloe vera could effectively decrease $L^{*}$ and $b^{*}$ values during the storage in comparison to the control.

Microbial count: Based on the results, use of $P$. psyllium as edible coating produced a $0.7 \log \mathrm{CFU} / \mathrm{g}$ decrease in the bacterial count. This was possibly seen due to high phenolic compounds in the $P$. psyllium mucilage. The higher the TPC in the mucilage, the higher the antimicrobial properties of the mucilage. This was possibly observed due to the diffused phenolic compounds into the cytoplasmic membrane, disrupted proton movement force and electrical current and coalescence cell contents.

\section{Conclusion}

In general, mucilage edible coating helps improvement of physicochemical qualities of freshly-cut apples. Results from the present study showed increased PPO of freshlycut apples with significant differences between the control and other treatments. Increased PPO was higher in control samples than other treatment samples. During the storage, firmness of the samples increased gradually. Furthermore, samples treated with $P$. psyllium and the control sample respectively demonstrated the highest and lowest levels of tissue firmness during ten days of storage. Increased storage time was associated to significantly decreased total phenol contents of the samples treated with $P$. major and the control. In contrast, samples treated with $P$. psyllium and $D$. Sophia showed no significantly decreased total phenol contents. Moreover, samples treated with D. Sophia and the control sample respectively demonstrated the lowest and highest levels of BI during ten days of storage. Samples treated with $P$. psyllium and the control sample respectively demonstrated the highest and lowest inhibitory effects on the bacterial growth during ten days of storage. In conclusion, $P$. psyllium L. mucilage can be recommended as a novel edible coating to improve the quality of freshly-cut apples.

\section{Financial disclosure}

The authors declared no financial interest.

\section{Funding/Support}

This work was financially supported by the Agricultural Sciences and Natural Resources University of Khuzestan.

\section{References}

1. Moreira MR, Cassani L, Martín-Belloso O, SolivaFortuny R. Effects of polysaccharide-based edible coatings enriched with dietary fiber on quality attributes of fresh-cut apples. Journal of Food Science and Technology. 2015;52(12):7795-805.

2. Noshad M, Mohebbi M, Ansarifar E. Quantification of enzymatic browning kinetics of quince preserved by edible coating using the fractal texture Fourier image. Journal of Food Measurement and Characterization. 2015;9(3):375-81.

3. Vargas M, Pastor C, Chiralt A, McClements DJ, González-Martínez C. Recent advances in edible coatings for fresh and minimally processed fruits. Critical Reviews in Food Science and Nutrition. 2008;48(6):496-511.

4. Hernández-Muñoz P, Almenar E, Del Valle V, Velez D, Gavara R. Effect of chitosan coating combined with postharvest calcium treatment on strawberry (Fragariax ananassa) quality during refrigerated storage. Food Chemistry. 2008;110(2):428-35.

5. Benítez S, Achaerandio I, Pujolà M, Sepulcre F. Aloe vera as an alternative to traditional edible coatings used in fresh-cut fruits: A case of study with kiwifruit slices. LWT-Food Science and Technology. 2015;61(1):18493.

6. Nasiri M, Barzegar M, Sahari M, Niakousari M. Application of Tragacanth gum impregnated with Satureja khuzistanica essential oil as a natural coating for enhancement of postharvest quality and shelf life of button mushroom (Agaricus bisporus). International journal of biological macromolecules. 2018;106:21826.

7. Soukoulis C, Gaiani C, Hoffmann L. Plant seed mucilage as emerging biopolymer in food industry applications. Current Opinion in Food Science. 2018.

8. Samuelsen AB. The traditional uses, chemical constituents and biological activities of Plantago major L. A review. Journal of ethnopharmacology. 2000;71(12):1-21.

9. Lukova P, Karcheva-Bahchevanska D, Nikolova M, Iliev IN, Mladenov R. Comparison of structure and antioxidant activity of polysaccharides extracted from the leaves of Plantago major L., P. media L. and P. lanceolata L. 2017. 
10. Mohamed NH, Mahrous AE. Chemical constituents of Descurainia sophia L. and its biological activity. Records of natural products. 2009;3(1):58.

11. Krystyjan M, Khachatryan G, Ciesielski W, Buksa K, Sikora M. Preparation and characteristics of mechanical and functional properties of starch/Plantago psyllium seeds mucilage films. Starch-Stärke. 2017.

12. Chen $\mathrm{C}, \mathrm{Hu} \mathrm{W}$, He Y, Jiang A, Zhang R. Effect of citric acid combined with UV-C on the quality of fresh-cut apples. Postharvest Biology and Technology. 2016;111:126-31.

13. Chen S, Zhang M, Wang S. Physiological and quality responses of Chinese 'Suli'pear (Pyrus bretschneideri Rehd) to 1-MCP vacuum infiltration treatment. Journal of the Science of Food and Agriculture. 2010;90(8):1317-22.

14. Barakat M, Shehab S, Darwish N, El-Zoheiry E. A new titrimetric method for the determination of vitamin $\mathrm{C}$. Analytical biochemistry. 1973;53(1):245-51.

15. Eisele TA, Drake SR. The partial compositional characteristics of apple juice from 175 apple varieties. Journal of food composition and analysis. 2005;18(2$3): 213-21$.

16. Hoehn E, Gasser F, Guggenbühl B, Künsch U. Efficacy of instrumental measurements for determination of minimum requirements of firmness, soluble solids, and acidity of several apple varieties in comparison to consumer expectations. Postharvest Biology and Technology. 2003;27(1):27-37.

17. Liu H, Chen F, Yang H, Yao Y, Gong X, Xin Y, et al. Effect of calcium treatment on nanostructure of chelatesoluble pectin and physicochemical and textural properties of apricot fruits. Food Research International. 2009;42(8):1131-40.

18. Waterhouse AL. Determination of total phenolics. Current protocols in food analytical chemistry. 2002.

19. Friedman M, Bautista FF. Inhibition of polyphenol oxidase by thiols in the absence and presence of potato tissue suspensions. Journal of agricultural and food chemistry. 1995;43(1):69-76.
20. Brand-Williams W, Cuvelier M-E, Berset C. Use of a free radical method to evaluate antioxidant activity. LWT-Food science and Technology. 1995;28(1):25-30.

21. Rößle C, Brunton N, Gormley RT, Wouters R, Butler F. Alginate Coating as Carrier of Oligofructose and Inulin and to Maintain the Quality of Fresh- Cut Apples. Journal of food science. 2011;76(1).

22. Jafari S, Hojjati M, Noshad M. Influence of soluble soybean polysaccharide and tragacanth gum based edible coating to improve the quality of fresh- cut apple slices. Journal of Food Processing and Preservation. 2018:e13638.

23. Brasil I, Gomes C, Puerta-Gomez A, Castell-Perez M, Moreira R. Polysaccharide-based multilayered antimicrobial edible coating enhances quality of freshcut papaya. LWT-Food Science and Technology. 2012;47(1):39-45.

24. Shin Y, Liu RH, Nock JF, Holliday D, Watkins CB. Temperature and relative humidity effects on quality, total ascorbic acid, phenolics and flavonoid concentrations, and antioxidant activity of strawberry. Postharvest Biology and Technology. 2007;45(3):34957.

25. Saba MK, Sogvar OB. Combination of carboxymethyl cellulose-based coatings with calcium and ascorbic acid impacts in browning and quality of fresh-cut apples. LWT-Food Science and Technology. 2016;66:165-71.

26. Qi H, Hu W, Jiang A, Tian M, Li Y. Extending shelflife of fresh-cut 'Fuji' apples with chitosan-coatings. Innovative Food Science \& Emerging Technologies. 2011;12(1):62-6.

27. Ferree DC, Warrington IJ. Apples: botany, production, and uses: CABI; 2003.

28. Macheix J-J, Fleuriet A. Fruit phenolics: CRC press; 1990.

29. Chauhan O, Raju P, Singh A, Bawa A. Shellac and aloe-gel-based surface coatings for maintaining keeping quality of apple slices. Food Chemistry. 2011;126(3):961-6. 